\title{
The Influence of Procrastination and Low Time Management on Student Self Efficacy (at MA Soebono Mantofani)
}

\author{
Kharisma Danang Yuangga ${ }^{1}$, Denok Sunarsi ${ }^{2}$ \\ 1.2 Universitas Pamulang \\ E-mail: danangyuangga@gmail.com
}

(Received: February-2018; Reviewed: March-2018; Accepted: July-2018;

Avalaibel Online: September-2018; Published: September-2018)

S This is an open access article distributed under the Creative Commons Attribution License CC-BY-NC-4.0 @2018 by author (https://creativecommons.org/licenses/by-nc/4.0/)

\begin{abstract}
Procrastination is the behavior that can not take advantage of time or procrastinate doing something. The purpose of this study was to determine the effect of procrastinating habits and low time management on student self efficacy in MA Soebono Mantofani. The method used is descriptive method with an associative approach. The sampling technique used was proportional random sampling using a sample of 61 respondents. The analysis tool uses validity test, reliability test, classic assumption test, regression analysis, correlation coefficient analysis, coefficient of determination analysis and hypothesis testing. The results of this study are the delaying habits have a negative effect on student self-efficacy of $41.0 \%$. Hypothesis testing is obtained $t_{\text {count }}<t_{\text {table }}$ or $(-6,406<2,001)$, so that H0 is accepted and H1 is rejected, meaning that there is no positive and significant influence between procrastination on student selfefficacy in MA Soebono Mantofani. The low time management has a negative effect on student selfefficacy by $39.9 \%$. Hypothesis testing is obtained $t_{\text {count }}<t_{\text {table }}$ or $(-6.262<2.001)$ so that H0 is accepted and $\mathrm{H} 2$ is rejected, meaning that there is no positive and significant influence between low management time on student slf Efficacy on. Simultaneous test of procrastinating habit and low time management affect the student self efficacy with a contribution of $41.7 \%$, while the remaining $58.3 \%$ is influenced by other factors. Hypothesis testing obtained the value of $F_{\text {count }}>F_{\text {table }}$ or (20.767> 2.760), thus Ho is rejected and $\mathrm{H} 3$ is accepted. This means that there is a simultaneous influence between procrastinating habits and low time management on student self efficacy in MA Soebono Mantofani.
\end{abstract}

Keywords: Procrastination; time management; student self-efficacy.

\section{INTRODUCTION}

At MA Soebono Mantofani found the behavior of students who often felt difficulty in doing something according to a predetermined time limit, such as not collecting assignments on time, completing homework, to the habit of not being able to keep promises in accordance with the agreement. This gives rise to various forms of impact on students' habits, namely students often experience delays in coming to school, students prepare things very excessively, and are 
unable to complete work or assignments optimally. The student's behavior can also be called Procurement. Procrastination is a behavior that cannot be efficient in using time (Gunawinata \& Lasmono, 2008; Novi, 2019; Susilowati, Sutriyono, Riyani, Prasetya, \& Wahyudiati, 2011; Zahra \& Hernawati, 2015). That can happen because it does not immediately start a task or job. Besides that, it can be interpreted as a form of avoidance of tasks because of feelings of discomfort, fear of failure of the task at hand. Procrastination is also an individual's negative trait or habit towards the response to work on a task (Adrianta \& Tjundjing, 2007; Jannah \& Muis, 2014; Khairat, Maputra, \& Rahmi, 2014; Mutakien, 2015; Pradinata \& Susilo, 2016). The indications presented can be directed at the behavior of not being able to use time effectively. Behavior can not take advantage of time or procrastinate doing something called procrastination. Individuals who do procrastination called procrastinator. (Endrianto, 2014; Husetiya, 2015; Marlina, 2015; Mubasyir, 2016; Purwanti \& Wibowo, 2015).

Procrastination is the delay or delay in completing a task and is categorized as a failure of self-regulation (Steel, 2007). Procrastination can be seen from certain restrictions, among others: procrastination is only as a behavior of procrastination, namely every act to delay doing a task, without disputing the purpose and reason for the delay; procrastination as a habit or pattern of individual behavior that leads to the trait, the delay is a permanent response that is always done in the face of the task, usually accompanied by irrational beliefs; procrastination as a personality trait, procrastination is not only delaying behavior, but it is a trait that involves behavioral components and other mental structures that are interrelated and can be known directly or indirectly. Procrastination is always associated with the ability to manage time (Sunarsi, 2018a, 2018b).

Time management is the ability to put time and resources to achieve goals. This ability can create a balance between work and personal life. Concentrate on results and not just keep yourself busy. Time management not only refers to time management but rather tends to use time. Individuals who are able to manage time will determine the priorities of the various tasks faced, focus time and energy on important tasks first. Time management related to life management is the achievement of the main goals of life as a result of setting aside meaningless activities that often take a lot of time. This ability will shape self-assessment/self-efficacy (Baird, 1981; Farrell, 2017; Quazi, 2017).

Etymologically self-efficacy consists of two words, namely "self" as an element of personality structure and "efficacy" which means self-assessment, efficacy refers to the attitude of whether being able to do good or bad, right or wrong, able or unable to do something as required (Dewi, 2012; Johari et al., 2009; Lai Mooi, 2006; Yusof et al., 2011). Menurut (Bandura, 1977, 2006) self-efficacy consists of three dimensions, namely: magnitude refers to the level of difficulty of the task that is believed to be able to overcome it. The level of selfefficacy of individuals differs from one another. The level of difficulty of a task, whether difficult or easy, will determine self-efficacy. In a task or activity, if there is no significant obstacle to overcome, then the task will be very easy to do and everyone must have high selfefficacy; generality refers to variations in situations in which self-efficacy judgments are applied. Individuals can judge themselves to have efficacy in many activities or on certain activities. Weak self-efficacy can be known for example when faced with a task that has a high level of difficulty, the tendency to delay and avoid doing it will be chosen more. This is different from students who have strong beliefs, students will try as much as possible in their efforts to solve challenges despite many obstacles.

\section{METHOD}

The type of data used is quantitative with primary data sources by distributing questionnaires which are then carried out tabulation and feasibility analysis as well as secondary 
data from the various scientific literature. The population in this study was MA students Soebono Mantofani, totaling 155 students. Sampling was used (Hidayat, 2017) formula technique with an error rate of $10 \%$ to obtain a sample of 61 students. The instrument testing uses validity and reliability tests. From the validity and reliability test stated valid and reliable, this is evidenced by the value of $r_{\text {count }}>r_{\text {table }}$, likewise, the instrument used is appropriate and feasible to be forwarded to the next test. Testing for normality using Kolmogorov Smirnov obtained significance greater than 0.50 and thus declared normal. Multicollinearity testing obtained tolerance values $<1$ and VIF $<10$ so that it was concluded there was no interference with multicollinearity. Autocorrelation testing obtained the value of Durbin-Watson at an interval of 1.550 - 2.460, thus this regression model does not have autocorrelation. Heteroskesdastisitas test with the Glejser test obtained a significance value greater than 0.05 so it was concluded that there was no interference with heteroscedasticity.

\section{RESULT AND DISCUSSION}

\section{Descriptive Analysis}

The criteria of the object under study are based on respondents' responses to the question items about the variable procrastination (X1), low time management (X2) and student selfefficacy (Y) as follows:

Table 1

Descriptive Score of Respondents' Answers

\begin{tabular}{l|r|r|r|r|r}
\hline \multicolumn{7}{c}{ Descriptive Statistics } \\
& N & Minimum & Maximum & Mean & \multicolumn{1}{c}{$\begin{array}{c}\text { Std. } \\
\text { Deviation }\end{array}$} \\
\hline Procrastination (X1) & 61 & 16 & 49 & 35.18 & 7.940 \\
\hline Low Time Management (X2) & 61 & 18 & 50 & 35.21 & 8.620 \\
\hline Self-efficacy (Y) & 61 & 17 & 46 & 31.46 & 6.879 \\
\hline Valid N (listwise) & 61 & & & & \\
\hline
\end{tabular}

The Procrastination Data obtained a minimum variance score of 16 and a maximum score of 49 and a ratting mean score of 35.18 and a standard deviation level of 7.940.

The low time management data obtained the results of a minimum variance score of 18 and a maximum score of 50 and a ratting mean score of 35.21 and a standard deviation level of 8.620.

Student's self-efficacy data obtained a minimum variance score of 17 and a maximum score of 46 and a ratting mean score of 31.46 and a standard deviation level of 6.879 .

\section{Verification Analysis}

Verification analysis is intended to determine the magnitude of the influence and analyze the significance of the influence. In this analysis carried out on the influence of two independent variables on the dependent variable. partially or simultaneously.

This multiple regression test is intended to find out how much influence the variables X1 and $\mathrm{X} 2$ have on the $\mathrm{Y}$ variable. In this study the habit of procrastination (X1) and low time management (X2) on student self efficacy (Y). The following are the results of processed regression data with SPSS version 26 which can be seen in the following table: 
Table 2

Results of Multiple Regression Processing Variables of Procrastinating Habits (X1) and Low Time Management (X2) on Student Self Efficacy (Y)

\section{Coefficients $^{\text {a }}$}

\begin{tabular}{|c|c|c|c|c|c|}
\hline \multirow[b]{2}{*}{ Model } & \multicolumn{2}{|c|}{$\begin{array}{l}\text { Unstandardized } \\
\text { Coefficients }\end{array}$} & \multirow{2}{*}{$\begin{array}{c}\text { Standardized } \\
\text { Coefficients } \\
\text { Beta } \\
\end{array}$} & \multirow[b]{2}{*}{$\mathrm{t}$} & \multirow[b]{2}{*}{ Sig. } \\
\hline & B & Std. Error & & & \\
\hline $1 \quad$ (Constant) & 50.820 & 3.136 & & 16.204 & .000 \\
\hline Procrastination (X1) & -.349 & .260 & -.403 & -1.340 & .185 \\
\hline Low Time Management (X2) & -.201 & .240 & -.252 & -.839 & .405 \\
\hline
\end{tabular}

Based on the results of the regression calculations in the above table, the regression equation $\mathrm{Y}=50.820-0.349 \mathrm{X} 1-0.201 \mathrm{X} 2$ can be obtained. A constant value of 50.820 means that if the procrastination (X1) and low time management (X2) variables are absent then there is a student self-efficacy (Y) value of 50.820 points. A value of -0.349 means that if the constant is constant and there is no change in the variable low time management (X2), then every 1 unit change in the procrastination (X1) variable will result in a change in student self-efficacy (Y) of -0,349 points. A value of -0.201 means that if a constant is constant and there is no change in the Procrastination (X1) variable, then every 1 unit change in the variable low time management (X2) will result in a change in student self-efficacy (Y) of -0.201 points.

Analysis of the coefficient of determination is intended to determine the percentage of the contribution of influence between the independent variables on the dependent variable both partially and simultaneously), in this study the variable procrastination (X1) and low time management (X2) on student self efficacy (Y). Here are the results of the calculation of the coefficient of determination, as follows:

Table 3

Partial Determination Coefficient Analysis Results Between Procrastination (X1) Against Student Self-Efficacy (Y)

\begin{tabular}{lrr|r|r|r}
\multicolumn{6}{c}{ Model Summary } \\
\hline Model & & & R Square & $\begin{array}{c}\text { Adjusted R } \\
\text { Square }\end{array}$ & $\begin{array}{c}\text { Std. Error of the } \\
\text { Estimate }\end{array}$ \\
\hline 1 & $\mathrm{R}$ & $.640^{\mathrm{a}}$ & .410 & .400 & 5.327 \\
\hline
\end{tabular}

a. Predictors: (Constant), Procrastination (X1)

Based on the test results in the table above, the R-Square value or determination of 0.410 is obtained, this shows that the contribution of the influence between the procrastination on student self-efficacy is $41.0 \%$, while the remaining $59.0 \%$ is influenced by other factors not researched.

Table 4

Partial Determination Coefficient Analysis Results Between Low Management Time (X2) Against Student Self Efficacy (Y)

\section{Model Summary}

\begin{tabular}{lr|rrrr}
\hline Model & R & R Square & \multicolumn{1}{c}{$\begin{array}{c}\text { Adjusted R } \\
\text { Square }\end{array}$} & $\begin{array}{c}\text { Std. Error of the } \\
\text { Estimate }\end{array}$ \\
\hline 1 & $.632^{\mathrm{a}}$ & .399 & .389 & 5.377 \\
\hline
\end{tabular}

a. Predictors: (Constant), Low Time Management (X2) 
Based on the test results in the table above, R-Square value or determination of 0.399 is obtained, this shows that the contribution of influence between low time management to student self efficacy is $39.9 \%$, while the remaining $60.1 \%$ is influenced by other factors that are not researched.

Table 5.

Results of Simultaneous Determination Coefficient Analysis Between Procrastinating Habits (X1) and Low Time Management (X2) Against Student Self Efficacy (Y)

\section{Model Summary}

\begin{tabular}{lr|rrr}
\hline Model & $\mathrm{R}$ & R Square & \multicolumn{1}{c}{$\begin{array}{c}\text { Adjusted R } \\
\text { Square }\end{array}$} & $\begin{array}{c}\text { Std. Error of the } \\
\text { Estimate }\end{array}$ \\
\hline 1 & $.646^{\mathrm{a}}$ & .417 & .397 & 5.341 \\
\hline
\end{tabular}

a. Predictors: (Constant), Low Time Management (X2), Procrastination (X1)

Based on the test results in the table above, R-Square value or determination of 0.417 is obtained, this shows that the contribution of the influence between the habit of procrastinating and the low time management simultaneously on student self efficacy is $41.7 \%$, while the remaining $58.3 \% \%$ is influenced by other factors not examined.

For testing the hypotheses variable procrastination (X1) and low time management (X2) on student self-efficacy $(\mathrm{Y})$ is done with a statistical test $\mathrm{t}$ (partial test).

The results of data processing using SPSS version 26, with the following results:

Table 6.

T-Test Results Procrastinating Variable (X1)

\section{Coefficients $^{\mathrm{a}}$}

\begin{tabular}{|c|c|c|c|c|c|c|}
\hline \multirow{2}{*}{\multicolumn{2}{|c|}{ Model }} & \multicolumn{2}{|c|}{$\begin{array}{l}\text { Unstandardized } \\
\text { Coefficients }\end{array}$} & \multirow{2}{*}{$\begin{array}{c}\text { Standardized } \\
\text { Coefficients } \\
\text { Beta } \\
\end{array}$} & \multirow{2}{*}{$\mathrm{t}$} & \multirow[b]{2}{*}{ Sig. } \\
\hline & & B & Std. Error & & & \\
\hline 1 & (Constant) & 50.979 & 3.123 & & 16.326 & .000 \\
\hline & Procrastination (X1) & -.555 & .087 & -.640 & -6.406 & .000 \\
\hline
\end{tabular}

a. Dependent Variable: Self-Efficacy (Y)

Based on the test results in the above table, the value of $t_{\text {count }}<t_{\text {table }}$ or $(-6,406<2,001)$ is obtained. Thus, H0 is accepted and H1 is rejected, this shows that there is no positive and partially significant effect between the habit of procrastinating on student's self-efficacy.

Table 7.

Test Results of Variable Low Time Management (X2)

\section{Coefficients $^{\mathrm{a}}$}

\begin{tabular}{|c|c|c|c|c|c|c|}
\hline \multirow{2}{*}{\multicolumn{2}{|c|}{ Model }} & \multicolumn{2}{|c|}{$\begin{array}{l}\text { Unstandardized } \\
\text { Coefficients }\end{array}$} & \multirow{2}{*}{$\begin{array}{c}\text { Standardized } \\
\text { Coefficients } \\
\text { Beta } \\
\end{array}$} & \multirow[b]{2}{*}{$\mathrm{t}$} & \multirow{3}{*}{$\frac{\text { Sig. }}{.000}$} \\
\hline & & $\mathrm{B}$ & Std. Error & & & \\
\hline \multirow[t]{2}{*}{1} & (Constant) & 49.214 & 2.918 & & 16.866 & \\
\hline & $\begin{array}{l}\text { Low Time Management } \\
\text { (X2) }\end{array}$ & -.504 & .081 & -.632 & -6.262 & .000 \\
\hline
\end{tabular}

a. Dependent Variable: Self-Efficacy (Y)

Based on the test results in the above table, the value of $t_{\text {count }}<t_{\text {table }}$ or $(-6,262<2,001)$ is obtained. Thus, $\mathrm{H} 0$ is accepted and $\mathrm{H} 2$ is rejected, this shows that there is no positive and partially significant effect between low time management on student self efficacy.

To test the effect of the variable of procrastination and low time management simultaneously on the self-efficacy of students at MA Soebono Mantofani was performed with a statistical test $\mathrm{F}$ (simultaneous test) with a significance of $5 \%$. 
Table 8

Simultaneous Hypothesis Results (Test F)

ANOVA $^{\mathrm{a}}$

\begin{tabular}{|c|c|c|c|c|c|c|}
\hline \multicolumn{2}{|c|}{ Model } & Sum of Squares & Df & Mean Square & $\mathrm{F}$ & Sig. \\
\hline \multirow[t]{3}{*}{1} & Regression & 1184.742 & 2 & 592.371 & 20.767 & $.000^{\mathrm{b}}$ \\
\hline & Residual & 1654.406 & 58 & 28.524 & & \\
\hline & Total & 2839.148 & 60 & & & \\
\hline
\end{tabular}

Based on the test results in the above table, the calculated $F_{\text {count }}>F_{\text {table }}$ or $(20.767>2.760)$ is obtained. Thus, H0 is rejected and $\mathrm{H} 3$ is accepted, this shows that there is a significant simultaneous effect between the habit of procrastinating and the low time management of the self-efficacy of MA Soebono Mantofani students.

\section{CONCLUSION}

Based on the research results delaying habits negatively affect student self-efficacy with a magnitude of influence of $41.0 \%$. Hypothesis testing obtained $t_{\text {count }}<t_{\text {table }}$ or $(-6,406<2,001)$. The low time management has a negative effect on student self-efficacy with a magnitude of influence of $39.9 \%$. Hypothesis testing obtained $t_{\text {count }}<t_{\text {table }}$ or $(-6,262<2,001)$. Procrastination and low time management has a negative effect on student self efficacy with a regression equation $\mathrm{Y}=50.820-0.349 \mathrm{X} 1-0.201 \mathrm{X} 2$. This is evidenced by the value of the regression coefficient that is negative. The amount of influence was $41.7 \%$ while the remaining $58.3 \%$ was influenced by other factors. Hypothesis testing obtained the value of $F_{\text {count }}>F_{\text {table }}$ or (20.767> 2.760), thus $\mathrm{H} 0$ is accepted and $\mathrm{H} 3$ is rejected. This means that there is a simultaneous influence between procrastinating habits and low time management on student self efficacy in MA Soebono Mantofani.

\section{REFERENCES}

Adrianta, E., \& Tjundjing, S. (2007). Mahasiswa Versus Tugas : Prokrastinasi Akademik dan Conscientiousness. Jounal Anima, Indonesian Psychological. https://doi.org/10.1086/512671

Baird, S. B. (1981). Time management. Journal of Intravenous Nursing. https://doi.org/10.5005/jp/books/12552_29

Bandura, A. (1977). Self-efficacy: Toward a unifying theory of behavioral change. Psychological Review. https://doi.org/10.1037/0033-295X.84.2.191

Bandura, A. (2006). Guide for constructing self-efficacy scales. Self-efficacy beliefs of adolescents. https://doi.org/10.1017/CBO9781107415324.004

Dewi, R. (2012). Kinerja Kepala Sekolah: Pengaruh Kepemimpinan Transformasional, Konflik Dan Efikasi Diri. Jurnal Ilmu Pendidikan Universitas Negeri Malang.

Endrianto, C. (2014). Hubungan Antara Self Control dan Prokrastinasi Akademik berdasarkan TMT. Jurnal Ilmiah Mahasiswa Universitas Surabaya.

Farrell, M. (2017). Time Management. Journal of Library Administration. 
https://doi.org/10.1080/01930826.2017.1281666

Gunawinata, V. A. R., \& Lasmono, H. K. (2008). Perfeksionisme, prokastinasi akademik, dan penyelesaian Skripsi Mahasiswa. Anima, Indonesia Psychological Journal.

Hidayat, A. (2017). Cara Hitung Rumus Slovin Besar Sampel.

Husetiya, Y. (2015). Hubungan Asertivitas Dengan Prokrastinasi Akademik Pada Mahasiswa Fakultas Psikologi Universitas Diponegoro Semarang. Jurnal Psikologi Universitas Diponegoro Semarang.

Jannah, M., \& Muis, D. T. (2014). Prokrastinasi Akademik (Perilaku Penundaan Akademik) Mahasiswa Fakultas Ilmu Pendidikan Universitas Negeri Surabaya. In Bk Unesa.

Johari, K., Ismail, Z., Osman, S., Othman, A. T., Khalid, J., Zurida, I., ... ahmad tajuddin, O. (2009). Pengaruh Kelayakan Guru ke atas Efikasi Guru-guru Sekolah Menengah. Jurnal Pendidikan Malaysia.

Khairat, U., Maputra, Y., \& Rahmi, F. (2014). Pengaruh Prokrastinasi Akademik Terhadap Perilaku Menyontek Pada Siswi SMA di Pesantren X. Jurnal RAP.

Lai Mooi, T. (2006). Self-efficacy and Student Performance in an Accounting Course. Journal of Financial Reporting and Accounting. https://doi.org/10.1108/19852510680001586

Marlina, M. (2015). Pengembangan Paket Manajemen Waktu untuk Mengurangi Prokrastinasi Akademik Siswa Sekolah Menengah Atas/ Sederajat. Bimbingan dan Konseling Ilmu Pendidikan, Universitas Negeri Surabaya.

Mubasyir, B. (2016). Hubungan antara Dukungan Sosial Teman Sebaya dengan Prokrastinasi Akademik Mahasiswa yang Mengikuti Unit Kegiatan Mahasiswa UIN Maulana Malik Ibrahim Malang. Universitas Islam Negeri Maulana Malik Ibrahim Malang.

Mutakien, T. Z. (2015). Analisis Prokrastinasi Tugas Akhir/Skripsi. Formatif: Jurnal Ilmiah Pendidikan MIPA. https://doi.org/10.30998/formatif.v2i1.87

Novi, W. (2019). Pengaruh Self-efficacy dan Prokastinasi Akademik Terhadap Motivasi Berprestasi Pada Mahasiswa PAUD IKIP Veteran Semarang. JCOSE Jurnal Bimbingan dan Konseling. https://doi.org/10.24905/jcose.v1i2.30

Pradinata, S., \& Susilo, J. D. (2016). Prokrastinasi Akademik dan Dukungan Sosial Teman Sebaya pada Mahasiswa Fakultas Psikologi Universitas Katolik Widya Mandala Surabaya. EXPERIENTIA : Jurnal Psikologi Indonesia.

Purwanti, E., \& Wibowo, A. R. A. (2015). Pengaruh Self-Regulated Learning , Self-Efficacy , Task Commitment Dan Kondisi Lingkungan Terhadap Prokrastinasi Akademik Pada Mahasiswa Kebidanan Merauke - Papua. Jurnal Poltekkes Jayapura.

Quazi, H. A. (2017). Time management. In Project Management: A Reference for Professionals. https://doi.org/10.1201/9780203741771

Steel, P. (2007). The nature of procrastination: A meta-analytic and theoretical review of quintessential self-regulatory failure. Psychological Bulletin. https://doi.org/10.1037/00332909.133.1.65

Sunarsi, D. (2018a). Pengaruh Gaya Kepemimpinan dan Disiplin Kerja Terhadap Kinerja Karyawan Pada CV. Usaha Mandiri Jakarta. JENIUS, 1(2).

Sunarsi, D. (2018b). Pengaruh Kompensasi, Komunikasi Dan Stress Kerja Terhadap Prestasi 


\section{Pinisi Discretion Review \\ Volume 2, Issue 1, September, 2018. Pages 85-92}

Kerja Karyawan Pada PT Catur Putra Jaya Kota Depok-Jawa Barat. JIMF (Jurnal Ilmiah Manajemen Forkamma), 1(2).

Susilowati, K., Sutriyono, S., Riyani, R., Prasetya, B. E. A., \& Wahyudiati, N. P. (2011). Hubungan antara tingkat self-efficacy dengan perilaku menyontek pada mahasiswa di Universitas Muhammadiyah Gresik. Jurnal Psikosains. https://doi.org/10.24246/j.sw.2012.v28.i2.p127-136

Yusof, M. H. M., Muda, A., Makmom, A., Samah, B. A., Basri, R., Rashid, N. a., \& Alias, M. K. (2011). Faktor-Faktor yang Mempengaruhi Efikasi-Kendiri Guru Sekolah Menengah di Malaysia dalam Pelaksanaan Pendidikan Alam Sekitar terbitnya Buku Panduan Guru Pendidikan Alam Sekitar Merentas Kurikulum untuk sekolah. Malaysian Journal of Environmental Management.

Zahra, Y., \& Hernawati, N. (2015). Prokastinasi Akademik Menghambat Peningkatan Prestasi Akademik Remaja di Wilayah Perdesaan. Jurnal Ilmu Keluarga dan Konsumen. https://doi.org/10.24156/jikk.2015.8.3.163 